\title{
Growth potential, production efficiency and annual production of marine benthic naked amoebae (gymnamoebae) inhabiting sediments of the Clyde Sea area, Scotland
}

\author{
Helen Butler*, Andrew Rogerson** \\ University Marine Biological Station Millport, Isle of Cumbrae KA28 0EG, Scotland, UK
}

\begin{abstract}
A substantial population of naked amoebae is present in marine sediments, but little is known about their role in benthic microbial food webs. Central to elucidating this role is an understanding of their growth potential, and the present study measures growth rates of 10 species of naked amoebae isolated from benthic sediments in the Clyde Sea area, Scotland, UK. Across the range of species and temperatures examined $\left(5\right.$ to $\left.20^{\circ} \mathrm{C}\right)$, generation times varied from 11 to $130 \mathrm{~h}$. Temperature had a marked effect on growth rate, with the slowest rates at the lowest temperature. Temperature also generally influenced the mean cell volume of cells, with many species showing increased cell size at lower temperatures. Consequently, it was possible to compute a significant regression of $\log _{10}$ generation time $(G, h)$ agalnst $\log _{10}$ cell volume $\left(V, \mu \mathrm{m}^{3}\right)$ using the combined data regardless of temperatures $[\log G=0.231 \log V+1.010(p=0.004)]$. This relationship may have application in the estimation of generation times of naked amoebae with known cell volumes. Gross growth efficiencies ranged between 11.7 and $79.7 \%$ with an overall mean of $36.1 \%$. The growth data were combined with published information on the abundance of marine benthic amoebae to provide a first estimate of annual production by this group in fine marine sediments. Annual production estimates were between 7.60 and $15.8 \mathrm{~kJ}$ $\mathrm{m}^{-2} \mathrm{yr}^{-1}$, implying that annual consumption of bacteria by naked amoebae is of the order 21.1 to $43.8 \mathrm{~kJ}$ $\mathrm{m}^{-2} \mathrm{yr}^{-1}$
\end{abstract}

KEY WORDS: Benthos - Carbon cycling - Microorganisms - Protozoa

\section{INTRODUCTION}

At the present time our knowledge of the ecological importance of naked amoebae with lobose pseudopodia, the gymnamoebae, in marine benthic sediments is extremely limited. Recent sudies have demonstrated that naked amoebae are abundant in the Clyde Sea (Scotland, UK) area, numbering up to $15600 \mathrm{ml}^{-1}$ in the plankton and $15000 \mathrm{~cm}^{-3}$ in the benthos (Rogerson \& Laybourn-Parry 1992, Anderson \& Rogerson 1995, Butler \& Rogerson 1995). To elucidate the potential contribution of the naked amoebae to carbon flow in the sea, it is crucial to understand their growth potential.

- Present address: British Antarctic Survey, Cambridge CB3 OET, United Kingdom

*Addressee for correspondence.

E-mail: a.rogerson@udcf.gla.ac.uk
There are few published studies on the growth rates of free-living naked amoebae, particularly for marine species, the only study being one by Bunt (1970) on an algivorous amoeba. Published experiments on soil amoebae include those of Heal (1967) on Acanthamoeba sp., Cutler \& Crump (1927) on Hartmannella hyalina, and Rogerson \& Berger (1981) on Naegleria gruberi. Experiments on freshwater amoebae have focused on the large Polychaos fasciculatum and Amoeba proteus and on 6 smaller species (Baldock \& Baker 1980, Baldock et al. 1980, Rogerson 1980). In addition, Arndt (1993) has estimated the growth rate of a community of freshwater amoebae in a lake.

Other relevant studies have looked at the growth rates of species of testate amoebae (Laybourn \& Whymant 1980) and heliozoa (Tobiesen 1991). There is far more literature on the growth rates of ciliates and flagellates (e.g. Phelps 1946, Fenchel 1969, Taylor \& 
Berger 1976, Caron et al. 1986, Darbyshire et al. 1993), however, rates may not be comparable for all. types of heterotrophic protists, given recent evidence that the energetic costs of locomotion in amoebae are far greater than those incurred by ciliates and flagellates (Crawford et al. 1994).

In the present study, the growth rates of representative naked amoebae spanning a wide size range were measured. Morphotypes were isolated from the benthos of the Clyde Sea area and cultured under defined laboratory conditions. Experiments were carried out at $5,10,15$ and $20^{\circ} \mathrm{C}$, to encompass the range of in situ temperatures experienced in marine sediments in temperate regions. This is the first study to consider growth and production in marine bacterivorous gymnamoebae.

\section{MATERIALS AND METHODS}

Species and culture. Ten species of naked amoebae were isolated during 1991 from the benthos of the Clyde Sea area (Fig. 1). The sediments at 4 sites ranged from mud to fine sand and all amoebae were isolated from the upper aerobic layer. Amoebae were maintained in culture at $5,10,15$ and $20^{\circ} \mathrm{C}$ in Modified Erdschreiber medium (MErds, Page 1983) with the bacterium Planococcus citreus (NCIMB 1493, Aberdeen, UK) as the primary food source. The species of amoebae studied, with their mean lengths, were as follows: Clydonella rosenfieldi $(17.4 \mu \mathrm{m})$, Dactylamoeba sp. $(53.1 \mu \mathrm{m})$, Paraflabellula reniformis $(26.9 \mu \mathrm{m})$, Platyamoeba sp. $(5.6 \mu \mathrm{m})$, Rhizamoeba sp. $(15.8 \mu \mathrm{m})$, Stereomyxa ramosa $(199 \mu \mathrm{m})$, Vahlkampfia baltica $(19.4 \mu \mathrm{m})$, Vahlkampfia damariscottae $(12.0 \mu \mathrm{m})$, Vannella caledonica $(19.9 \mu \mathrm{m})$ and Vannella sp. $(8.1 \mu \mathrm{m})$.

Measurement of growth rates. Amoebae from exponentially growing cultures acclimatised at the appropriate experimental temperature were washed several times by decanting off the old culture medium and replacing with fresh MErds. Throughout this procedure most amoebae remained firmly attached to the base of the culture dish and the majority of bacteria wcre removed. Washed amoebae were suspended in a small volume of MErds and $100 \mu \mathrm{l}$ of this concentrated cell suspension was added to each of 5 replicate $50 \mathrm{~mm}$ diameter petri dishes containing $10 \mathrm{ml}$ of MErds. Knowing the exact number of cells in the inoculum was not critical, since growth rate is independent of the size of the initial inoculum (Baldock et al. 1980). In all cases, the bacterium Planococcus citreus was added as a food source, at a density similar to that found in local marine sediments (around $2.5 \times 10^{8} \mathrm{~cm}^{-3}$ sediment). Initial experiments showed that this prey concentra-

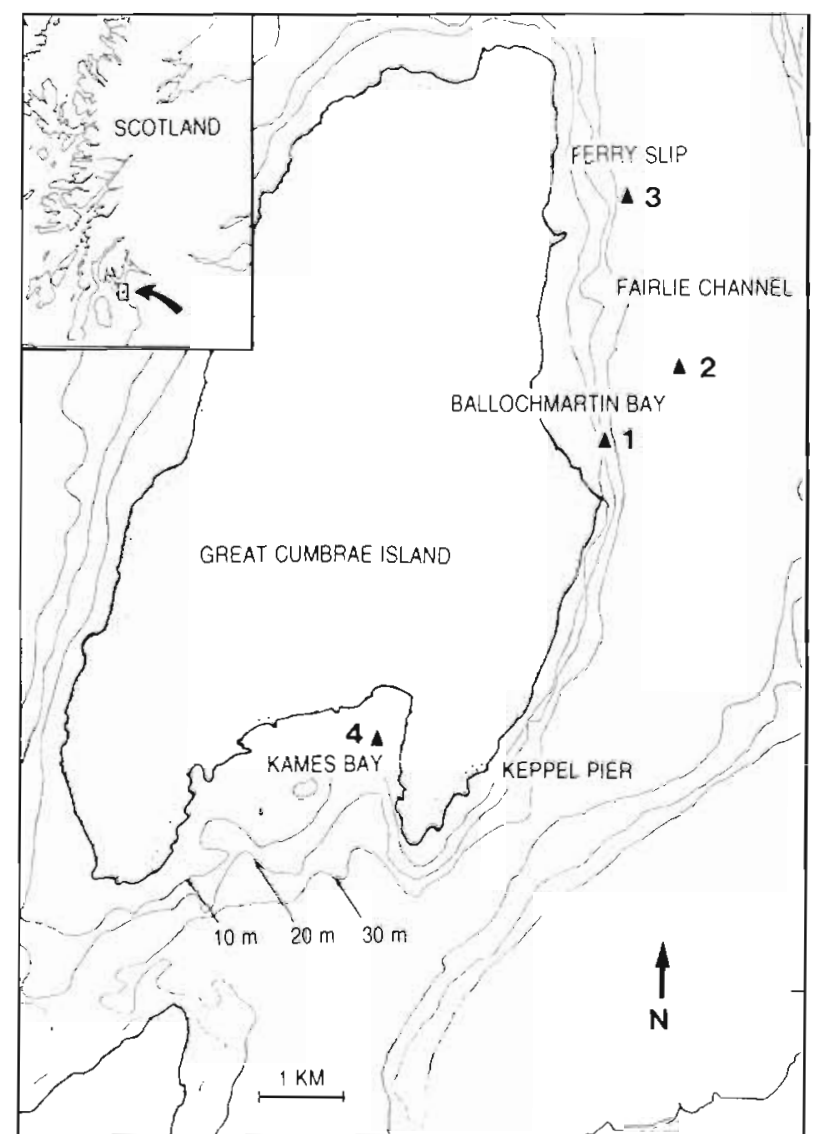

Fig. 1. Map showing the position of sampling sites ( 1 to 4 ) in the Clyde Sea area, Scotland, UK

tion was within the range giving optimal amoebal growth rates (Butler unpubl.).

Amoebae were incubated overnight at the required experimental temperature to allow cells to acclimate to the new culture conditions. The number of cells in 20 random fields of view was then determined for each replicate dish at $t_{0}$ and at appropriate time intervals thereafter, using an inverted phase contrast microscope with an overall magnification of $400 \times$. Growth rates and generation times for each species were calculated from regressions of $\log _{10}$ mean number of amoebae against time extending over the period of exponential growth.

Estimation of amoeba cell volumes. Cultures were fixed in Lugol's iodine at the termination of each experiment. This induced some amoebae to round-up and form spheres (Rogerson et al. 1994). The diameters of 50 rounded cells for each species at each temperature were measured using an eyepiece graticule and the average cell volume $\left(\mathrm{mm}^{3}\right)$ for each species calculated. It is important to note that these volumes may be slight underestimates because fixing protozoan cells can cause a degree of shrinkage (Choi \& Stoecker 1989). 
Estimation of growth efficiency. The percentage gross growth efficiency (GGE = Production/Consumption $\times 100$ ) gives a measure of how much consumed biomass $\left(\mu^{3}\right)$ appears as production. Production over the cell cycle was approximated as $0.66 \times$ measured mean

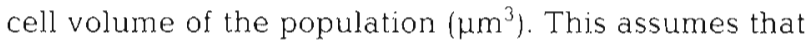
newly divided cells double in volume over the cell cycle and that growth is linear, as has been shown for Amoeba proteus (Rogerson 1981). Total bacterial uptake $\left(\mu \mathrm{m}^{3}\right)$ over the cell cycle was estimated from mean specific rates calculated for 6 of the amoebae used in the present study: i.e. interspecific means of 0.042 , $0.050,0.084$, and 0.131 bacteria $\mathrm{h}^{-1} \mu \mathrm{m}^{-3}$ amoeba biomass for $5,10,15$, and $20^{\circ} \mathrm{C}$, respectively (Butler \& Rogerson unpubl. data). In all cases, the volume of a single prey bacterium used in the consumption experiments was $0.8 \mu^{3}$. No attempt was made to convert the biomass $\left(\mu \mathrm{m}^{3}\right)$ data to energy equivalents (e.g. carbon or joules) since there is no clear consensus on appropriate conversion factors. For example, in the case of bacteria, factors range markedly from 0.12 to $0.56 \mathrm{pg} \mathrm{C}$ $\mu^{-3}$ (Bjornsen 1986) while the value for protozoa (based on Monas sp.) is $0.22 \mathrm{pg} \mathrm{C} \mathrm{mm}^{-3}$ (Borsheim \& Bratbak 1987). By retaining the data in the form of biomass units $\left(\mu \mathrm{m}^{3}\right)$ the calculated efficiencies were within the expected range for protozoa (see 'Discussion'). This suggests that a bacterial conversion similar to that of Monas sp. may be appropriate for marine bacteria.

Estimation of annual production. Annual production was estimated from the growth rate data (present study) and from amoeba abundance data gathered throughout 1991 (Butler \& Rogerson 1995). In this enumeration study, numbers of bacterivorous amoebae were estimated by an enrichment cultivation method. Sediment was diluted and $1 \mu$ aliquots were dispensed into soil extract medium (Page 1983) contained in wells of tissue culture plates. These were incubated at $18^{\circ} \mathrm{C}$ in the dark. Based on the number of culture dish wells with populations of amoebae, the number of amoebae in undiluted sediment was calculated. Data on abundances were collected from 4 benthic sites in the Clyde Sea area (Fig. 1): Site 1 was fine sand at $18 \mathrm{~m}$, Sites 2 and 3 were medium and coarse silt at $46 \mathrm{~m}$ and $38 \mathrm{~m}$, respectively and Site 4 was fine sand at $8 \mathrm{~m}$. In all cases, amoebae were counted in the surface, aerobic layer (usually the top $1 \mathrm{~cm}$ ) and the numerical data were transformed to biomass equivalents $\left(\mu \mathrm{m}^{3}\right)$ using the cell volume data. Production was calculated by Calkorskaja's formula for continuously reproducing populations as reported in Kajak (1967). This method has been used previously for amoebae by Heal (1970) and Rogerson (1982) and for benthic protozoa (Finlay 1978). Kajak's formula is as follows:

$$
P=[1 / D]\left[\left(B_{0}+B_{t}\right) / 2\right] \times t
$$

where $P$ is production during $t$ time units, $D$ is doubling time in days and $B_{0}$ and $B_{t}$ are the initial and final biomass values with regard to time $t$. It is important to note that this expression assumes that growth is at a constant (maximum) rate over time. This is clearly an oversimplification of conditions in the field so the production value generated by this equation merely gives an order-of-magnitude estimate of amoeba production.

To facilitate comparisons with published production values, results were converted to energy and carbon equivalents. Unfortunately, few conversion factors are available in the literature and none are published for marine amoebae. At this time, the most appropriate values are the conversions relating biomass to dry

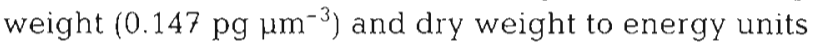
(17.51 $\mathrm{J} \mathrm{mg}^{-1}$ dry weight) derived for a freshwater amoeba, Amoeba proteus (Rogerson 1979). Production values $\left(\mu^{3}{ }^{3}\right.$ ) were also converted to carbon equivalent units using a value of $0.22 \mathrm{pg} \mathrm{C} \mathrm{m}^{-3}$ derived for the flagellate Monas sp. (Børsheim \& Bratbak 1987).

The estimation of production and production efficiency in this study allowed us to calculate an estimate of annual consumption by naked marine amoebae in benthic sediments. Again, because of the aforementioned limitations of the annual production estimate, this can only be considered to be an order-of-magnitude estimate. However, it does provide new information on the potential impact of this group on bacterial production in the benthos.

\section{RESULTS}

The relationship between $\log _{10}$ number of amoebae and time (h) was linear and in every case the fit of the regression line was significant $(p<0.05)$ with the exception of Dactylamoeba sp., which repeatedly failed to grow at $5^{\circ} \mathrm{C}$. The growth rates $\left(\mathrm{h}^{-1}\right)$ and generation times (h) of all species of amoebae calculated from the regressions are given in Table 1.

Generation times varied with both species and temperature, ranging from $11.2 \mathrm{~h}$ for Platyamoeba sp. at $20^{\circ} \mathrm{C}$ to $130 \mathrm{~h}$ for Rhizamoeba sp. at $5^{\circ} \mathrm{C}$. All species grew fastest at $20^{\circ} \mathrm{C}$ and slowest at $5^{\circ} \mathrm{C}$, except Stereomyxa ramosa, which had the shortest generation time at $15^{\circ} \mathrm{C}$. The $95 \%$ confidence intervals of the slopes of the regression lines showed that the growth rates of most species cultured at different temperatures were significantly different. Where they were not, the $95 \%$ confidence intervals of the $y$-axis intercept were also calculated. Platyamoeba sp., Vahlkampfia baltica and Clydonella rosenfieldi had growth rates at each temperature that were significantly different $(p<0.05)$ from rates at the other temperatures. However, no significant difference $(p>0.05)$ was found in growth rates of $V$. 
damariscottae between 5 and $15^{\circ} \mathrm{C}$, in Vannella sp. between 5 and $10^{\circ} \mathrm{C}$ and between 15 and $20^{\circ} \mathrm{C}$, in Paraflabellula reniformis between 10 and $15^{\circ} \mathrm{C}$ and in Dactylamoeba sp. between 10 and $15^{\circ} \mathrm{C}$. Vannella

Table 1. Growth rate constant $\left(\mu, \mathrm{h}^{-1} \times 10^{2}\right)$, generation time $\left(G_{4}\right.$ $h)$, mean cell volume ( $\mathrm{MCV} \pm \mathrm{SE}, \mu \mathrm{m}^{3}$ ) and percentage gross growth efficiencies (GGE) for 10 species of manne amoebae cultured at 4 temperatures. ng: no growth; nd: no data

\begin{tabular}{|c|c|c|c|c|c|}
\hline Species & $T\left({ }^{\circ} \mathrm{C}\right)$ & $\mu$ & $G$ & $\mathrm{MCV}$ & GGE \\
\hline \multicolumn{6}{|c|}{ Clydonella rosenfieldi } \\
\hline & 5 & 0.94 & 74.0 & $700(56)$ & 26.5 \\
\hline & 10 & 1.22 & 57.0 & $469(30)$ & 28.9 \\
\hline & 15 & 2.62 & 26.5 & $308(20)$ & 37.0 \\
\hline & 20 & 5.57 & 12.5 & $385(36)$ & 50.3 \\
\hline \multicolumn{6}{|c|}{ Dactylamoeba sp. } \\
\hline & 5 & $\mathrm{ng}$ & $\mathrm{ng}$ & $\mathrm{ng}$ & ng \\
\hline & 10 & 0.67 & 103.2 & $3258(645)$ & 16.0 \\
\hline & 15 & 0.83 & 83.7 & $2832(164)$ & 11.7 \\
\hline & 20 & 2.02 & 34.3 & $1685(141)$ & 18.3 \\
\hline \multicolumn{6}{|c|}{ Paraflabellula reniformis } \\
\hline & 5 & 1.08 & 64.4 & $437(35)$ & 30.1 \\
\hline & 10 & 2.48 & 28 & $392(36)$ & 58.9 \\
\hline & 15 & 3.51 & 19.8 & $587(53)$ & 49.6 \\
\hline & 20 & 3.99 & 17.4 & $387(43)$ & 36.1 \\
\hline \multicolumn{6}{|c|}{ Platyamoeba sp. } \\
\hline & 5 & 2.15 & 32.2 & $60(9)$ & 60.9 \\
\hline & 10 & 2.87 & 24.2 & $26(2)$ & 68.8 \\
\hline & 15 & 3.24 & 21.4 & nd & nd \\
\hline & 20 & 6.21 & 11.2 & $28(2)$ & 56.0 \\
\hline \multicolumn{6}{|c|}{ Rhizamoeba sp. } \\
\hline & 5 & 0.53 & 130.0 & $430(30)$ & 15.1 \\
\hline & 10 & 1.04 & 66.9 & $148(12)$ & 24.7 \\
\hline & 15 & 1.27 & 54.8 & $57(6)$ & 17.9 \\
\hline & 20 & 2.30 & 30.2 & $83(5)$ & 20.8 \\
\hline \multicolumn{6}{|c|}{ Stereomyxa ramosa } \\
\hline & 5 & 0.67 & 103.8 & $564(48)$ & 18.9 \\
\hline & 10 & 0.80 & 87.0 & $835(80)$ & 18.9 \\
\hline & 15 & 1.59 & 43.7 & $575(58)$ & 22.5 \\
\hline & 20 & 1.52 & 45.8 & $1453(140)$ & 13.7 \\
\hline \multicolumn{6}{|c|}{ Vahlkampfla baltica } \\
\hline & 5 & 0.98 & 70.6 & $566(40)$ & 27.9 \\
\hline & 10 & 1.10 & 63.0 & $361(27)$ & 26.2 \\
\hline & 15 & 2.95 & 23.5 & $283(20)$ & 41.8 \\
\hline & 20 & 4.38 & 15.8 & $301(19)$ & 31.9 \\
\hline \multicolumn{6}{|c|}{ Vahlkampfia damariscottae } \\
\hline & 5 & 1.09 & 63.4 & $68(9)$ & 31.0 \\
\hline & 10 & 3.33 & 20.8 & $154(9)$ & 79.7 \\
\hline & 15 & 3.22 & 21.5 & $83(13)$ & 45.7 \\
\hline & 20 & 5.50 & 12.6 & $45(4)$ & 50.3 \\
\hline \multicolumn{6}{|c|}{ Vannella caledonica } \\
\hline & 5 & 1.83 & 38.0 & $525(18)$ & 51.6 \\
\hline & 10 & 2.48 & 28.0 & 431 (23) & 58.8 \\
\hline & 15 & 260 & 267 & $352(19)$ & 36.7 \\
\hline & 20 & 2.93 & 23.7 & $300(18)$ & 26.6 \\
\hline \multicolumn{6}{|c|}{ Vannellasp. } \\
\hline & 5 & 1.28 & 54.3 & $46(3)$ & 36.2 \\
\hline & 10 & 1.71 & 40.4 & $37(3)$ & 40.7 \\
\hline & 15 & 3.16 & 22.0 & $41(3)$ & 44.4 \\
\hline & 20 & 4.53 & 15.3 & $38(3)$ & 41.1 \\
\hline
\end{tabular}

caledonica only showed a significant difference in growth rate when comparing results from the temperature extremes $5^{\circ} \mathrm{C}$ and $20^{\circ} \mathrm{C}$.

The mean cell volumes for each species at each temperature are also given in Table 1 . To determine the interspecific relationship between cell volume $(V)$ and generation time $(G)$, the $\log _{10} G$ on $\log _{10} V$ data were regressed for each temperature (Fig. 2). The regression was only significant $(p<0.05)$ at $20^{\circ} \mathrm{C}$ and the regression lines for each temperature were not significantly different from each other $(p>0.05)$. Therefore, a combined regression using data from all 4 temperatures was calculated as $\log _{10} G(\mathrm{~h})=0.231 \log _{10} V\left(\mu \mathrm{m}^{3}\right)+1.010 ; \mathrm{p}=0.004$.

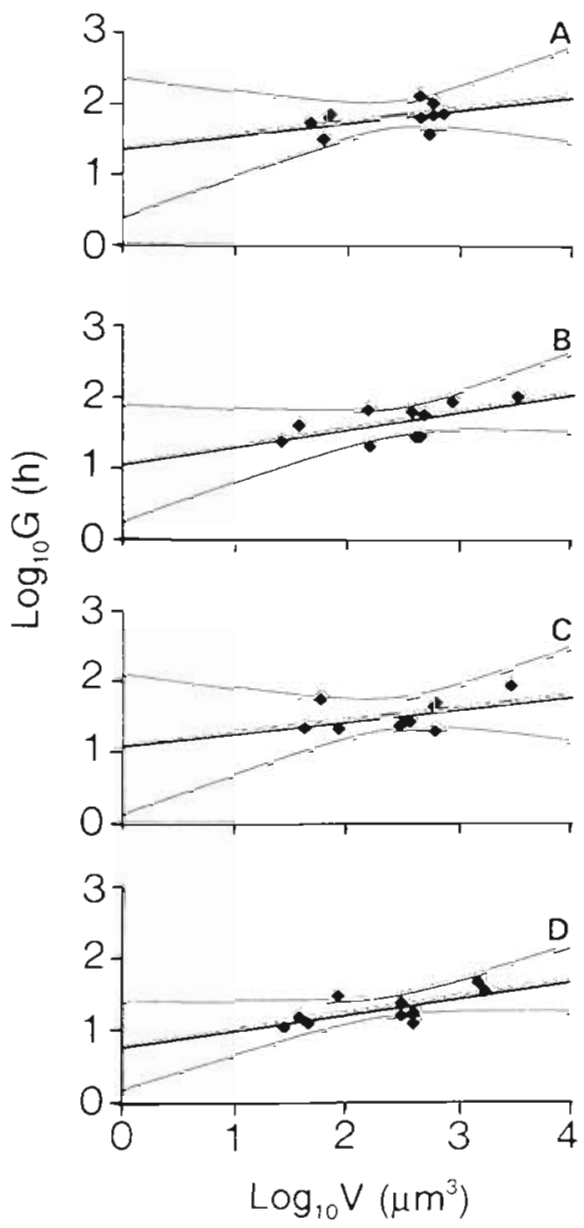

Fag. 2. Plots of $\log _{10}$ generation time $(G)$ against $\log _{10}$ cell volume $(V)$ for amoebae cultured at 4 experimental temperatures with $95 \%$ confidence limits (CL). Equations of the lines are as follows:

(A) At $5^{\circ} \mathrm{C}, \log _{10} G=0.187 \log _{10} V+1.360(95 \% \mathrm{CL}$ of slope and intercept are 0.306 and 0.747 , respectively).

(B) At $10^{\circ} \mathrm{C}, \log _{30} G=0.245 \log _{10} V+1.061(95 \% \mathrm{CL}$ of slope and intercept are 0.254 and 0.632 , respectively).

(C) At $15^{\circ} \mathrm{C}, \log _{10} G=0.168 \log _{10} V+1.092(95 \%$ CL of slope and intercept are 0.302 and 0.747 , respectively).

(D) At $20^{\circ} \mathrm{C}, \log _{10} G=0.221 \log _{10} V+0.780(95 \% \mathrm{CL}$ of slope and intercept are 0.153 and 0.451 , respectively) 
Growth efficiencies ranged from 11.7 to $79.7 \%$, with an overall mean of $36.1 \%$ (Table 1 ). In most cases, efficiencies were lowest at $5^{\circ} \mathrm{C}$ and increased with temperature

Annual production levels for naked amoebae inhabiting the aerobic layer of benthic sediments are shown in Table 2. Generally, the finest sediments contained higher numbers of amoebae, particularly in the top $0.5 \mathrm{~cm}$ layer. If this surface layer is considered, the site with the highest production is Site 2, where the sediments are $87 \%$ silt and clay. However, if the complete aerobic zone of the sediment at each site is considered, the total production is highest for the sandy Site 4. Although there are far fewer amoebae at each depth and a lower production in the surface $0.5 \mathrm{~cm}$ at Site 4, the aerobic layer extends to about $15 \mathrm{~cm}$, whereas in the finer sediments it is restricted to the top 1 or $2 \mathrm{~cm}$.

\section{DISCUSSION}

The generation times calculated for marine amoebae in the present study are similar to those reported in other studies on amoebae. For example, experiments on freshwater amoebae by Baldock et al. (1980), at temperatures between 10 and $25^{\circ} \mathrm{C}$, found generation times to range from 4.5 to $33.3 \mathrm{~h}$. Baldock \& Baker (1980) reported doubling times of $23.5 \mathrm{~h}$ at $25^{\circ} \mathrm{C}$ to $323 \mathrm{~h}$ at $5^{\circ} \mathrm{C}$ for Polychaos fasciculatum and Heal (1967) calculated generation times of 17 to $240 \mathrm{~h}$ for Acanthamoeba sp at 5 to $25^{\circ} \mathrm{C}$. Comparable results, ranging between 2.4 and $46 \mathrm{~h}$, have also been obtained for benthic cilates at $20^{\circ} \mathrm{C}$ (Fenchel 1968).

The importance of temperature in the regulation of growth rate of amoebae is clear. Over the range of temperatures used in the study, growth rate increased (i.e. generation time decreased) with temperature. Such a relationship has previously been found for other amoebae (Heal 1967, Baldock \& Baker 1980, Baldock et al. 1980, Rogerson 1981).

The temperatures measured for the surface sediments in the Clyde Sea area, from which the amoebae were isolated, ranged from approximately 6 to $15^{\circ} \mathrm{C}$ over 1991. The results therefore indicate that all 10 species examined are capable of reproducing in situ throughout the year, apart from Dactylamoeba sp., which did not grow at $5^{\circ} \mathrm{C}$. Attempts to grow 4 of the species at $1^{\circ} \mathrm{C}$ were only successful in the case of $V$. damariscottae. Normal growth over the range of temperatures found in the field is supported by the fact that $93 \%$ of the $Q_{10}$ values were below 5.0 and $56 \%$ of the values were less than 3.0. Wieser (1973) speculated that low $Q_{10}$ values indicate that an organism is in the optimum part of its temperature range, whereas high
Table 2. Annual production of the entire naked amoebae community inhabiting the aerobic layer of benthic marine sediments of the Clyde Sea area

\begin{tabular}{|lcccc|}
\hline Units & \multicolumn{4}{c}{ Site } \\
& 1 & 2 & 3 & 4 \\
\hline $\mathrm{kJ} \mathrm{m}^{-2} \mathrm{yr}^{-1}$ & 7.60 & 15.7 & 9.86 & 15.8 \\
$\mathrm{~g} \mathrm{C} \mathrm{m} \mathrm{yr}^{-1}$ & 0.65 & 1.34 & 0.84 & 1.35 \\
\hline
\end{tabular}

values of around 6 to 10 are found towards the limit of an organism's metabolic tolerance.

Nine of the 10 species of amoebae studied had their maximum growth rates at 15 or $20^{\circ} \mathrm{C}$, suggesting that amoebae tend to grow at sub-maximal rates in situ. Optimum temperatures for growth above those encountered in the field have been demonstrated for other species of amoeba (Baldock \& Baker 1980, Baldock et al. 1980) and for marine benthic ciliates (Fenchel 1968).

A significant regression of growth rate on temperature for protozoa was first described by Fenchel (1968) for marine benthic ciliates and similar relationships have been demonstrated for other protozod (Fenchel 1974, Finlay 1977, Baldock et al. 1980, Montagnes et al. 1988, Muller \& Geller 1993). In the present study, which is the first to consider marine amoebae, a linear relationship was found between $\log _{10}$ generation time and $\log _{10}$ cell volume, with a slope of $0.231( \pm 0.153)$, which is not significantly different $(p>0.05)$ from the slope of 0.311 obtained by Baldock et al. (1980) for a range of freshwater amoebae and ciliates. Their study also found that the regression lines at the separate experimental temperatures were not significantly different from each other. Such generalizations should be used with care in future studies on amoebal growth because of the difficulties of accurately estimating amoebal cell volume. In our study there is considerable variation in the data, and the inverse relationship between cell volume and temperature, which accounts for the temperature-independent generalized relationship, is not consistent across all species examined (Table 1).

Fenchel (1987) presented a relationship between log growth rate $\left(\mathrm{h}^{-1}\right)$ and log cell volume $\left(\mu \mathrm{m}^{-3}\right)$ for a wide range of protozoa at $20^{\circ} \mathrm{C}$. Here, the growth rate constant decreased with around the 0.25 power of cell volume and showed that sarcodines appeared to have consistently lower growth rate constants than other protozoa. The data from the present study at $20^{\circ} \mathrm{C}$ showed similar results in terms of the slope of the line $(-0.22)$ and the positioning of the amoeba data points below those of ciliates and flagellates. It is not clear why amoebae of similar size to flagellates and ciliates should have lower growth rates. A high respiratory 
cost of locomotion (as suggested by Crawford et al. 1994) could account for slightly lower growth constants, with less energy being channelled to growth. It is more likely that lower growth potential in amoebae is an adaptive feature of the group. Fenchel (1987) speculated that protozoa living in relatively homogeneous environments, with excess food, would have no selective advantage in having very rapid growth.

No significant relationship was found between cell volume and temperature, although $70 \%$ of the amoebae examined had greater cell volumes at the lowest temperatures at which they could be grown. For example, the cell volume of Rhizamoeba sp. was some $5 x$ greater at $5^{\circ} \mathrm{C}$ than at higher temperatures. The extended generation times at these lower temperatures show that some cells can lay down new biomass and increase in size without undergoing cell division. An increase in cell volume at lower temperatures has been noted for other species of amoebae (Baldock \& Baker 1980, Rogerson 1981).

The growth efficiencies varied from 11.7 to $79.7 \%$, with a mean of $36.1 \%$. The highest values may reflect problems in accurately measuring the cell volumes and consumption rates of amoebae. However, the majority of efficiencies in Table 1 are well within the range published for other protozoa, with most lying between 30 and $50 \%$ (Fenchel 1987), the variation being due to inherent differences among species and to the qualitative nature of the prey. In most cases, efficiencies increased with increasing temperature, suggesting that amoebae converted food into biomass with increased efficiency at the higher temperatures. The 2 morphotypes with the lowest efficiencies, Dactylamoeba sp. and Stereomyxa ramosa, had the largest cell volumes. It is possible that these species would have yielded higher efficiencies if fed prey other than bacteria, since both have been found by us to readily ingest protistan prey such as pennate diatoms.

Extrapolation of laboratory data to the field situation must be handled with care, the natural environment being more complex because of the many interacting environmental factors. However, the temperatures and food concentrations in our experiments were chosen to be as similar as possible to those in the sediments, and amoebae were surface-attached, as in the benthos. Laboratory growth rates were measured during exponential growth of the population, but this is a reasonable simplification since exponential growth of protozoa in the field has been observed (Fenchel 1968, Bick 1973). Additionally, Arndt (1993) found generation times of a community of naked amoebae from Lake Muggelsee to be similar when measured in the laboratory and in situ.

When applied to field data, the results of the present study provide first information on the production of benthic marine amoebae. The annual production values, ranging between 7.6 and $15.8 \mathrm{~kJ} \mathrm{~m}^{-2} \mathrm{yr}^{-1}$, depending on sediment type, demonstrate the potential ecological importance of this group in the benthos. It must be stressed, however, that these values can only be viewed as order-of-magnitude estimates, because of the assumptions that are inevitable in such calculations (Schönborn 1992). Even so, these levels are important since there are few comparable data in the literature. The only study for marine sediments is that of Fernandez-Leborans \& Novillo (1993), who found that amoeba annual production in sublittoral beach sand ranged between 3.4 and $24.7 \mathrm{~kJ} \mathrm{~m}^{-2} \mathrm{yr}^{-1}$, a range that included all amoebae, not just naked forms.

Production values calculated in the present study are within the range quoted for naked amoebae from other habitats. Production was slightly lower for amoebae attached to plants in a chalk stream $\left(6.2 \mathrm{~kJ} \mathrm{~m}^{-2} \mathrm{yr}^{-1}\right.$; Baldock et al. 1983) and slightly higher for amoebae inhabiting Sphagnum moss $\left(49.7 \mathrm{~kJ} \mathrm{~m}^{-2} \mathrm{yr}^{-1}\right.$; Rogerson 1982). The value reported by Heal (1967) for soil amoebae is 2 orders of magnitude greater, reflecting the importance of naked amoebae in soils.

By using the average gross production efficiency value $(36.1 \%$ ) calculated for amoebae in this study, it is possible to estimate how much bacterial biomass amoebae crop each year in marine sediments. Annual consumption by amoebae was $1.80,3.71,2.33$ and $3.74 \mathrm{~g} \mathrm{C} \mathrm{m}^{-2} \mathrm{yr}^{-1}$ for Sites $1,2,3$ and 4, respectively. Sander \& Kalff (1993) compiled data from 25 studies on bacterial production in sediments. Using their data to calculate an average annual bacterial production value (350.4 g C m $\mathrm{g}^{-2} \mathrm{yr}^{-1}$ ), amoebae therefore consume between 0.5 and $1.1 \%$ of the total bacterial production. However, if their lowest bacterial production value is used $\left(0.4 \mathrm{~g} \mathrm{C} \mathrm{m}^{-2} \mathrm{yr}^{-1}\right)$, then the entire benthic assemblage of naked amoebae could consume between 450 and $935 \%$ of bacterial production.

Clearly, without reliable data on bacterial production values and possible prey preferences of amoebae in marine sediments, it is impossible to draw firm conclusions about the exact ecological. role of this group Perhaps the major contribution of this paper is that it draws attention to a frequently overlooked group of protists in the benthos and demonstrates that they need to be considered in future studies of carbon flow.

Acknowledgements. This research was supported by a NERC studentship awarded to H.B.

\section{LITERATURE CITED}

Anderson OR, Rogerson A (1995) Annual abundances and growth potential of gymnamoebae in the Hudson Estuary with comparative data from the Firth of Clyde. Eur J Protistol 31:223-233 
Arndt $H$ (1993) A critical revue of the importance of rhizopods (naked and testae amoebae) and actınopods (helizoa) in lake plankton. Mar Microb Food Webs 7:3-29

Baldock BM, Baker JH (1980) The occurrence and growth rates of Polychaos fasciculatum, a re-discovered amoeba. Protistologica 16:79-83

Baldock BM, Baker JH, Sleigh MA (1980) Laboratory growth rates of six species of freshwater Gymnamoebia. Oecologia 47:156-159

Bick H (1973) Population dynamucs of protozoa associated with the decay of organic materials in fresh water Am Zool 13:149-160

Bjornsen PK (1986) Automatic determination of bacterioplankton biomass by image analysis. Appl Environ Microbiol 51:1199-1204

Borsheim KY, Bratbak G (1987) Cell volume to cell carbon conversion factors for a bacterivorous Monas sp. enriched from seawater. Mar Ecol Prog Ser 36:171-175

Bunt JS (1970) Preliminary observations on the growth of a naked marine amoeba. Bull Mar Sci 20:315-330

Butler H, Rogerson A (1995) Temporal and spatial abundance of naked amoebae (gymnamoebae) in marine benthic sediments of the Clyde Sea area, Scotland. J Euk Microbiol 42:724-730

Caron DA, Davis PG, Madin LP, Sieburth JMcN (1986) Enrichment of microbial populations in macroaggregates (marine snow) from surface waters of the North Atlantic. J Mar Res 44:543-565

Choi JW, Stoecker DK (1989) Effects of fixation on cell volume of marine planktonic protozoa. Appl Environ Microbiol 55: $1761-1765$

Crawford DW, Rogerson A, Laybourn-Parry J (1994) Respiration of the marine amoeba Trichosphaerium sieboldi determined by ${ }^{14} \mathrm{C}$ labelling and Cartesian diver methods. Mar Ecol Prog Ser 112:135-142

Cutler DW, Crump LM (1927) The qualitative and quantitative effects of food on the growth of a soil amoeba (Hartmannella hyalina). Brit J Exp Biol 5:155-165

Darbyshire JF, Zwart KB, Elston DA (1993) Growth and nutrogenous excretion of a common soll flagellate, Cercomonas sp. Soil Biol Biochem 25:1583-1589

Fenchel T (1968) The ecology of marine microbenthos IIT. The reproductive potential of cilıates. Ophelia 5:123-136

Fenchel T (1969) The ecology of manne microbenthos IV: structure and function of the benthic ecosystem. Ophelia $6: 1-182$

Fenchel T (1974) Intrinsic rate of natural increase: the relationship with body size. Oecologia 14:317-326

Fenchel T (1987) Ecology of Protozoa. Science Tech Publishers, Madison, WI

Fernandez-Leborans G, Novillo A (1993) Sublittoral protistan communities of the shores of the Sea of Cantabria (Bay of Biscay). Int Rev Ges Hydrobiol 78:201-218

Finlay BJ (1977) The dependence of reproductive rate on cell size and temperature in freshwater ciliated protozoa. Oecologia 30:75-81

Finlay BJ (1978) Community production and respiration by ciliated protozoa in the benthos of a small eutrophic loch. Freshwater Biol 8:327-241

Responsible Subject Editor: J. Dolan, Villefranche-sur-Mer, France
Heal OW (1967) Quantitative feeding studies on soll amoebae. In: Graff $O$, Satchell JE (eds) Progress in soll biology. North Holland Publishing Co., Amsterdan

Heal OW (1970) Methods of study of soil protozoa. In: Phillipson $\mathrm{J}$ (ed) Methods of study of soil ecology. UNESCO. Paris

Kajak Z (1967) Remarks on methods of investigating benthos production. Ekologia Polska Ser B 13:173-195

Laybourn J, Whymant L. (1980) The effect of diet and temperature on reproductive rate of Arcella vulgaris Ehrenberg (Sarcodina: Testacida). Oecologia 45:282-284

Montagnes DJS, Lynn DH, Roff JC, Taylor WD (1988) The annual cycle of heterotrophic planktonic ciliates in the waters surrounding the Isles of Shoals, Gulf of Maine: an assessment of their trophic role. Mar Biol 99:21-30

Müller H, Geller W (1993) Maximum growth rates of aquatic ciliated protozoa: the dependence on body size and temperature reconsidered. Arch Hydrobiol 126 : $315-327$

Page FC (1983) Marine gymnamoebae. Institute of Terrestrial Ecology, Cambridge

Phelps A (1946) Growth of protozoa in pure culture III. Effect of temperature upon the division rate. J Exp Zool 102: $177-192$

Rogerson A (1979) Energy content of Amoeba proteus and Tetrahymena pyriformis (Protozoa). Can J Zool 57: 2463-2465

Rogerson A (1981) The ecological energetics of Amoeba proteus (Protozoa). Hydroblologla 85:117-128

Rogerson A (1982) An estimate of the annual production and energy flow of the large naked amoebae population inhabiting a Sphagnum bog. Arch Protistenkde 126: $145-149$

Rogerson A, Berger J (1981) Effect of crude oil and petroleum-degrading micro-organisms on the growth of freshwater and soil protozoa. J Gen Microbiol 124:53-59

Rogerson A, Butler HG, Thomason JC (1994) Estimation of amoeba cell volume from nuclear diameter and its application to studies in protozoan ecology. Hydrobiologia 284 : 229-234

Rogerson A, Laybourn-Parry J (1992) The abundance of marine naked amoebae in the water column of the Clyde Estuary. Estuar Coast Shelf Sci 34:187-196

Sander BC, Kalff J (1993) Factors controlling bacterial production in marine and freshwater sediments. Microb Ecol 26:79-99

Schönborn W (1992) Comparative studies on the production biology of protozoan communities in freshwater and soil ecosystems. Arch Protistenkde 41:187-214

Taylor WD, Berger J (1976) Growth responses of cohabiting ciliate protozoa to various prey bacteria. Can J Zool 54: 1111-1114

Tobiesen A (1991) Growth rates of Heterophyrys marina (Heliozoa) on Chrysochromulina polylepis (Prymnesiophyceae). Ophelia 33:205-212

Wieser W (1973) Temperature relations of ectotherms: a speculative review. In: Wieser W (ed) Effects of temperature on ectothermic organisms. Springer-Verlag, Berlin

Manuscript first received: January 31, 1996

Revised version accepted: March 11, 1996 